\title{
11 Embedded careers education
}

\author{
Lucas Walsh and Joanne Gleeson
}

\section{How to use this policy}

Changes in global labour markets, increasing competition for employment and changing shapes of traditional careers are creating challenges for young Australians as they leave school for different employment, education and training pathways. Sound and comprehensive careers education is critical to ensure students develop knowledge of post-school pathways and labour markets, employability skills, career goals and plans, as well as the confidence to make career-related decisions. This policy highlights how schools can appropriately and effectively support students planning and enacting their post-school transitions through the provision of a comprehensive careers education approach. This policy example is intentionally broad and school policy creators are encouraged to delete and build upon suggestions below to create a policy that best represents their school.

[To adapt and use this policy, delete or modify the text as indicated]

\section{[INSERT name of school]: Embedded careers education}

\section{Rationale}

Recent decades have seen changes in labour markets that greatly impact young Australians (Black \& Walsh, 2019). For example, there has been a rise in casual, part-time and on-call work (Hajkowicz et al., 2016; International Labour Organization [ILO], 2020), with Australia having one of the highest proportions of employees engaged in temporary jobs compared to other countries (Organization for Economic Co-operation and Development [OECD], 2019). An aging population also means that Australians are working longer, which intensifies competition for work (Thomas \& Gilfillan, 2019). Other trends such as automation are changing the types of jobs available, with over a third of all current jobs in Australia at risk of disappearing or significantly changing in profile in coming years (OECD, 2019). For young people, these changes mean fewer permanent 
available jobs, intense competition for work and declining working conditions. Over half of all young Australian workers are in casual jobs and are getting paid less, experiencing lower working standards and suffering from less job security than older employees (Dhillon \& Cassidy, 2018). They also want to work more but are finding it difficult to do so. A third of Australian youth are now unemployed or underemployed, with youth unemployment more than double that of the wider working population (Australian Bureau of Statistics [ABS], 2020; OECD, 2019).

Further, these changes are impacting how young people understand the concept of a career. The traditional idea of a single, stable, career is being replaced by a "portfolio career", with young people today expected to have as many as 17 different jobs over five careers in their lifetime (Foundation for Young Australians [FYA], 2017, p. 6; Inkson, 2015). The long-held assumption that higher education qualifications will lead to desirable and secure work is also being challenged (Chesters \& Wyn, 2019). Even medium to highly educated young people are finding it difficult to obtain work (OECD, 2019), with university graduates sometimes experiencing a mismatch between their qualifications and available jobs (Karmel \& Carroll, 2016). This does not mean that higher education qualifications are not crucial to securing desirable work; they just do not guarantee it. These trends are worrying Australian youth (Carlisle et al., 2018; 2019; Chesters \& Wyn, 2019; Wyn et al., 2017), who then feel pressured to continually seek credentials, experiences and higher levels of education to improve their employability (Black \& Walsh, 2019; Oinonen, 2018).

Young people need both the skills and aptitudes to navigate these postschool challenges, and careers education from the earliest age has been advocated as an effective and appropriate way to support them (Patton, 2017; Patton \& McMahon, 2014; Skorikov \& Patton, 2007; Watson \& McMahon, 2017).

\section{Purpose}

The key objective of this policy is to connect careers education at [INSERT name of school] with our school's aims, plans and curricula and involve the whole school community in better supporting students with their post-school transitions that are aligned with the 21 st-century workforce.

\section{Scope}

This policy applies to school management, teachers, staff, school-based careers advisors, and current students and parents/guardians of [INSERT name of school]. It also relates to community partners, such as employers. 


\section{Policy statement}

[INSERT name of school] acknowledges the nature of contemporary employment, higher education and training markets and is committed to supporting students through the provision of relevant and effective careers education that assists them to make successful post-school transitions. (Economic, Education, Jobs and Skills Committee [EEJSC], 2018; Torii \& O'Connell, 2017).

[INSERT name of school] believes students' career development needs to be fostered as an ongoing lifelong process of managing learning, work and life (Patton \& McMahon, 2014). Careers education from the earliest age is therefore essential and is a school priority (Patton, 2017; Skorikov \& Patton, 2007; Watson \& McMahon, 2017). Careers education will be provided to students from [INSERT Years] (i.e., Year 1 through Year 12) and will include structured, developmentally appropriate activities.

At [INSERT name of school] the post-school pathway or goal of each student will be valued and supported and not be judged relative to another student's plans or academic outcomes or the aims of the school overall (EEJSC, 2018). [INSERT name of school] recognises that post-school transitions look different for each individual student and will help students and their families understand the full breadth of transition opportunities available (Dik, Duffy, \& Eldridge, 2009; Duffy \& Sedlacek, 2007; Inkson, Dries, \& Arnold, 2015). [INSERT name of school's] careers education approach will therefore not disproportionately emphasise academic achievement and higher education pathways at the expense of other employment, education and training opportunities and destinations (Bowen \& Kidd, 2017; Torii \& O'Connell, 2017; Urbis, 2011). Students should understand the variety of pathways available post-school.

[INSERT name of school] believes it is important that our students experience a broad range of career-related activities that will help them build and master career skills to support effective post-school transitions (Ithaca Group, 2019; Polvere \& Lim, 2015).

[INSERT name of school] is committed to drawing on research evidence to supplement and improve our careers education approach (e.g., McMahon \& Patton, 2015) in line with professional standards and government guidelines (Career Industry Council of Australia [CICA], 2019; Department of Education \& Training [DET], 2019), as well as being responsive to the contemporary labour market and higher education challenges students may face.

\section{School management}

Clear careers education goals and program delivery expectations have been articulated in our school plans (Ithaca Group, 2019). [INSERT name of school] is committed to benchmarking the performance of our careers education program annually (CICA, 2014). Further, from [INSERT date], 
[INSERT name of school] will establish an advisory panel of business and other employer representatives and school partners to review the school's careers education approach and its connection to contemporary employment and education markets.

[INSERT name of school] commits to providing sufficient and capable resources to support the school's careers education agenda (Patton \& McMahon, 2014). As such, [INSERT name of school] has arranged professional development, internships, incursions and mentoring opportunities for teachers and advisors through external partnerships to improve their knowledge and capacities with regards to worlds-of-work and post-school employment, education and training opportunities for students. [INSERT suggested supplement] These partnerships and their benefits are listed in Supplement 1.

At [INSERT name of school] we are committed to utilising the latest resources and guidelines provided by state and federal governments that help us meet the aims and needs of our careers education approach (DET, 2019).

[INSERT name of school] has committed to partnering with a number of business, tertiary education, training and community partners to assist delivery of a relevant and comprehensive careers education program to our students (Lonsdale, 2011; Lonsdale et al., 2011; Torii, 2018; Walsh, 2016). [INSERT suggested supplement] These partnerships and related programs including the anticipated benefits to our students are listed in Supplement 2.

To ensure our careers education approach is as comprehensive and responsive to labour market changes as possible, individual counselling time between teachers, advisors and students has been prioritised for all [INSERT Years] (i.e., Year 1 through Year 12) students (Meijers \& Lengelle, 2012; Meijers, Lengelle, Winters, \& Kuijpers, 2017).

\section{Teachers and school advisors}

Teachers and school-based careers advisors will have the appropriate qualifications (CICA, 2019) where applicable and meet the professional development expectations, knowledge standards and performance criteria outlined in [INSERT name of school's] school plans (Ithaca Group, 2019).

Teachers and school-based advisors at [INSERT name of school] will endeavour to help students explore their own career identities (Savickas, 2011 ; 2012) such that their developing self-images can be connected with future careers and worlds-of-work (Côté \& Levine, 2016; Su, 2014).

To support our commitment to fostering lifelong career development approaches in students, teachers and school-based advisors at [INSERT name of school] are expected to adopt and role model lifelong learning attitudes and 
approaches to their own career development (McMahon \& Patton, 2000; Patton \& McMahon, 2014).

\section{Students}

Students' understanding and acknowledgement of post-school contemporary employment and education settings underpin [INSERT name of school's] careers education approach. Students will be assisted to acquire the skills and aptitudes necessary to take accountability for their own learning, exploration and decision-making regarding post-school transitions (Patton \& McMahon, 2014). This includes understanding their rights and responsibilities in the workplace as employees and potentially as employers or business owners. Further, [INSERT name of school] will commit to helping students develop employability and career management skills (Bridgstock, 2009; Tomlinson, 2017), in particular, resiliency and flexibility (del Corso, 2017; Duarte, da Silva, \& Paixão, 2017), as well as contingency career planning abilities (Borg, Pryor, \& Bright, 2014; Creed, Macpherson, \& Hood, 2011).

Students at [INSERT name of school] will experience a range of workbased learning, internships, volunteer programs and networking events, and school-based enterprise programs from [INSERT Years] (i.e., Year 1 through Year 12) to not only facilitate their connection with worlds-ofwork and allow for exploration of different vocations but to help them develop and apply employability and career management skills (Bowen \& Kidd, 2017; Eggleston, 2018; Polesel, Klatt, Blake, \& Starr, 2017; Pope, Berman, Tee, \& Williams, 2014; Rodriguez, Fox, \& McCambly, 2016). [INSERT suggested supplement] These work-related opportunities, including the anticipated benefits to our students, are listed in Supplement 3.

\section{Parents, guardians and broader school community}

[INSERT name of school] believes in the positive influences that parents, guardians and significant others can have on students' career development. We encourage all members of our broader school community to familiarise themselves with the careers education approach at [INSERT name of school] and support students by engaging in career conversations and exploration activities outside of school (Soresi, Nota, Ferrari, \& Ginevra, 2014; Watson \& McMahon, 2017).

[INSERT name of school] will seek to engage parents, guardians and students' significant others where possible in learning activities, information sessions and other communications forums regarding the importance of their roles in supporting students' career development (Ginevra, Nota, \& Ferrari, 2015; Patton, 2017; Watson \& McMahon, 2017). 


\section{Rating of evidence base}

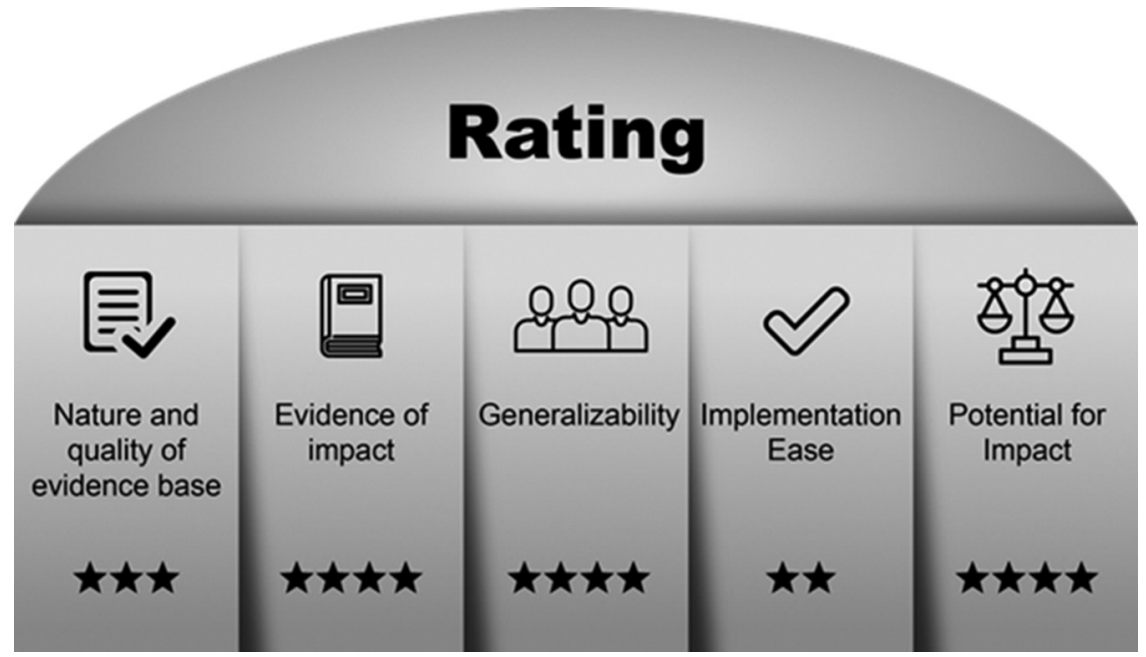

Figure 11.1. Embedded Careers Education Rating of Evidence.

Author Note. Substantial evidence exists regarding the benefits of careers education for students whilst at school. Relevant research has been referenced to support each policy statement. Whilst research acknowledges certain aspects of this policy as important (e.g., benchmarking careers education performance, school partnerships, teacher/advisor professional development through external partners, student career identity focus), additional or further Australian-based research would be beneficial. Much of the research referenced to support each policy statement includes evidence of impact. Some policy statements (e.g., recognising different career plans for each student and suspending judgement or comparison to others) would benefit from research and evidence impact extended to teachers' and school leaders' perspectives, not just students' perspectives. Consideration of different school contexts and student populations could have been more evident in the research supporting some policy aspects (e.g., benchmarking careers education performance, partnerships, teacher/advisor professional development through external partners). Policy reflects good practice that occurs in many schools already. Some recommended actions will require changes to curricula, development of relationships with external partners (if these don't already exist), expansion of existing careers education activities to younger year levels and investment in teacher/advisor professional development. There is excellent potential for impact if a comprehensive careers education approach is adopted and recommended actions implemented.

\section{Authorship}

Professor Lucas Walsh, Faculty of Education Monash University

Dr Joanne Gleeson, Faculty of Education Monash University

[INSERT relevant staff members]

\section{Related policy and documents}

[INSERT relevant policy and documents] 


\section{Date of ratification}

This policy was ratified on [INSERT date].

\section{Date of review}

This policy will be reviewed by [INSERT date].

\section{Supplements}

\section{Supplement 1: Teacher and school advisor careers education professional development opportunities at [INSERT name of school]}

\section{Partnership Program/ Opportunity Benefits}

e.g., ABCN Partners in Learning program https://www.abcn.com.au/ our-programs/developing-leaders

e.g., CICA \#Work2030 webinar discussion forums https://cica.org. au/projects/

e.g., Beacon Foundation Collaborative Classrooms program https://www.beaconfoundation. com.au/wp-content/uploads/2017/ 07/Beacon-Volunteering-BrochureFolded.pdf
Partners in Learning supports business and school leaders by linking them together to share experiences and expertise, solve problems and explore leadership challenges. It provides both leadership support for school principals beyond the education environment and the opportunity for business leaders to make a significant contribution to a school and the broader community.

An 8-part webinar series featuring panels of industry experts, career advisors and students providing opportunities for teachers and advisors to learn different perspectives regarding postschool transitions, ask questions and participate in online discussion forums.

A professional development workshop attended by teachers, advisors and business representatives who co-develop lesson plans that combine the school curriculum and authentic work practices.

\section{Supplement 2: External careers education opportunities for students at [INSERT name of school]}

Partnership Program/ Benefits

Opportunity

e.g., ABCN Aspirations program https://www. abcn.com.au/ourprograms/employabilityand-stem
Aspirations is a mentoring program for Year 11 students to broaden their awareness of career options and help them make informed decisions about their choices and pathways beyond school. Working in small groups, it provides students with an understanding of the skills required in a modern work environment including interview techniques and developing essential employability skills, while also exploring post-school options. 
e.g., Beacon Foundation Work Readiness programs https://www.beacon foundation.com.au/whatwe-do/high-impactprograms/

e.g., FYA Worlds of Work [WOW] program https://www.fya.org.au/ programs/worlds-of-work/

e.g., RMIT Careers and Employability session (Victorian-based opportunity) https://www.rmit. edu.au/events/2020/may/ steer-your-career
A series of half and one-day work readiness programs to boost employability skills and build real-life connections to worlds-of-work for students in Years 7-12. Programs are designed to ensure young people feel more confident and prepared for their transition from education into the workforce.

$W O W$ is an online program that equips young people with the enterprise skills and careers management skills to be prepared for the future of work. Tailored for students in Years 8-10, WOW activities facilitate meaningful career-linked experiences that aim to answer the question "What does it take to succeed in life and work?"

A workshop that introduces students to models of career development learning and how they can assist students to make a successful transition out of secondary school and beyond. Activities will provide students with the opportunity to do some self-reflection to assess where they are currently, understand what employers are looking for and consider what they can be doing inside and outside the classroom to achieve their goals.

\section{Supplement 3: Work-related experiences for students at [INSERT name of school]}

Experience
e.g., Work Experience Week video
project https://studyworkgrow.com.au/
work-experience/

e.g., Volunteering (South Australian context provided) https://www.educa tion.sa.gov.au/parenting-and-childcare/volunteers/student-volunteers/ student-volunteer-programs-benefitsand-approaches

\section{Benefits}

Each student secures a week of work experience, during which they interview individuals connected to different aspects of their experience and collect their reflections. Each student then creates a video of their experience which is presented to class and parents.

Series of integrated classes and volunteering opportunities. Each student secures a volunteering opportunity which is then incorporated into a series of classes and reflection activities over a term.

\section{References}

Australian Bureau of Statistics [ABS]. (2020). Labour force, Australia, April 2020, Cat. No.6202.0. https://www.abs.gov.au/ausstats/abs@.nsf/mf/6202.0

Black, R., \& Walsh, L. (2019). Imagining youth futures: University students in posttruth times. Springer.

Borg, T., Pryor, R. G. L., \& Bright, J. E. H. (2014). High school students - complexity, change and chance: Do the key concepts of the chaos theory of careers apply? Australian Journal of Career Development, 23(1), 22-28. 
Bowen, G., \& Kidd, E. (2017). Career guidance: The missing link in school to work transitions. Youth Action \& Policy Association. http://www.youthaction.org.au/ careers_guidance

Bridgstock, R. (2009). The graduate attributes we've overlooked: Enhancing graduate employability through career management skills. Higher Education Research \& Development, 28(1), 31-44.

Career Industry Council of Australia [CICA]. (2014). School career development service: Benchmarking resource. https://cica.org.au/wp-content/uploads/CICA-School-CareerBenchmarking-Resource1.pdf

Career Industry Council of Australia [CICA]. (2019). Professional standards for Australian career development practitioners. https:/cica.org.au/professional-standards/

Carlisle, E., Fildes, J., Hall, S., Hicking, V., Perrens, B., \& Plummer, J. (2018). Youth survey report 2018. Mission Australia. https://www.missionaustralia.com. au/publications/youth-survey

Carlisle, E., Hall, S., Fildes, J., \& Plummer, J. (2019). Working through it: A youth survey report on economically disadvantaged young people. Mission Australia. https:// www.missionaustralia.com.au/publications/youth-survey

Chesters, J., \& Wyn, J. (2019). Chasing rainbows: How many educational qualifications do young people need to acquire meaningful, ongoing work? Journal of Sociology, 55(4), 670-688.

Côté, J. E., \& Levine, C. G. (2016). Identity formation, youth, and development: A simplified approach. Psychology Press.

Creed, P., Macpherson, J., \& Hood, M. (2011). Predictors of "new economy" career orientation in an Australian sample of late adolescents. Journal of Career Development, 38(5), 369-389.

del Corso, J. J. (2017). Counselling young adults to become career adaptable and career resilient. In K. Maree (Ed.), Psychology of career adaptability, employability and resilience (pp. 171-188). Springer International.

Department of Education and Training [DET]. (2019). Future ready: A student focused national career education strategy. https://www.education.gov.au/national-careereducation-strategy

Dhillon, Z., \& Cassidy, N. (2018). Labour market outcomes for younger people: Bulletin, June 2018. Reserve Bank of Australia. https://www.rba.gov.au/publications/bulletin/ 2018/jun/labour-market-outcomes-for-younger-people.html

Dik, B. J., Duffy, R. D., \& Eldridge, B. M. (2009). Calling and vocation in career counseling: Recommendations for promoting meaningful work. Professional Psychology: Research and Practice, 40(6), 625-632.

Duarte, M. E., da Silva, J. T., \& Paixão, M. P. (2017). Career adaptability, employability, and career resilience in managing transitions. In K. Maree (Ed.), Psychology of career adaptability, employability and resilience (pp. 241-261). Springer International.

Duffy, R. D., \& Sedlacek, W. E. (2007). The presence of and search for a calling: Connections to career development. Journal of Vocational Behavior, 70, 590-601.

Economic, Education, Jobs and Skills Committee. (2018). Inquiry into career advice activities in Victorian schools. https://www.parliament.vic.gov.au/925-eejsc/inquiryinto-career-advice-activities-in-victorian-schools

Eggleston, J. (2018). Work experience in secondary schools. Routledge.

Foundation for Young Australians [FYA]. (2017). The new work smarts: Thriving in the new work order. https://www.fya.org.au/report/the-new-work-smarts/ 
Genevra, M. C., Nota, L., \& Ferrari, L. (2015). Parental support in adolescents' career development: Parents' and children's perceptions. The Career Development Quarterly, 63, 2-15.

Hajkowicz, S. A., Reeson, A., Rudd, L., Bratanova, A., Hodgers, L., Mason, C., Boughen, N. (2016). Tomorrow's digitally enabled workforce: Megatrends and scenarios for jobs and employment in Australia over the coming twenty years. CSIRO.

Inkson, K. (2015). Contemporary conceptualizations of career. In P. J. Hartung, M. L. Savickas, \& W. B. Walsh (Eds.), APA Handbook of career intervention (Vol. 1) (pp. 21-42). American Psychological Association.

Inkson, K., Dries, N., \& Arnold, J. (2015). Understanding careers: Metaphors of working lives (2nd edition). Sage.

International Labour Organization [ILO]. (2020). Non-standard forms of employment around the world: Understanding challenges, shaping prospects. https://www.ilo.org/ global/topics/non-standard-employment/lang-en/index.htm

Ithaca Group. (2019). Future ready: Research on incorporating career education in the Australian curriculum. DET. https://schooltowork.employment.gov.au/future-ready/ ithaca-group-future-ready-report

Karmel, T., \& Carroll, D. (2016). Has the graduate job market been swamped? NILS working paper series no. 228/2016. Flinders University, National Institute of Labour Studies. https://www.voced.edu.au/content/ngv:74196

Lonsdale, M. (2011). School-community partnerships in Australian schools. ACER. https://research.acer.edu.au/policy_analysis_misc/7/

Lonsdale, M., Deery, A., Clerke, S., Anderson, M., Curtin, E., Knight, P., \& Bramich, M. (2011). Final report: The benefits of school-business relationships. ACER. https:// research.acer.edu.au/policy_analysis_misc/8/

McMahon, M., \& Patton, W. (2000). Career counsellors, support and lifelong learning: A case for clinical supervision. International Journal for the Advancement of Counselling, 22, 157-169.

McMahon, M., \& Patton, W. (2015). Ideas for career practitioners: Celebrating excellence in career practice. Australian Academic Press.

Meijers, F., \& Lengelle, R. (2012). Narratives at work: The development of career identity. British Journal of Guidance \& Counselling, 40(2), 157-176.

Meijers, F., Lengelle, R., Winters, A., \& Kuijpers, M. (2017). A dialogue worth having: Vocational competence, career identity and a learning environment for twenty-first century success at work. In E. de Bruijn, S. Billett, \& J. Onstenk (Eds.), Enhancing teaching and learning in the Dutch vocational education system (PPBL Vol. 18) (pp. 139-155). Springer International.

Oinonen, E. (2018). Under pressure to become - from a student to entrepreneurial self. Journal of Youth Studies, 21(10), 1344-1360.

Organization for Economic Co-operation and Development [OECD]. (2019). The future of work: How does AUSTRALIA compare? OECD employment outlook 2019. OECD Publishing. http://www.oecd.org/australia/Employment-Outlook-AustraliaEN.pdf

Patton, W. (2017). Career adaptability, employability and resilience for children in early school years. In K. Maree (Ed.), Psychology of career adaptability, employability and resilience (pp. 207-223). Springer International.

Patton, W., \& McMahon, M. (2014). Career development and systems theory: Connecting theory and practice (3rd edition). Sense Publishers. 
Polesel, J., Klatt, M., Blake, D., \& Starr, K. (2017). Understanding the nature of school partnerships with business in delivery of vocational programmes in schools in Australia. Journal of Education and Work, 30(3), 283-298.

Polvere, R., \& Lim, P. (2015). Career development supporting young Australians: A literature review. NCVER. https://cica.org.au/wp-content/uploads/Career-Developm ent-supporting-young-Australians-2015.pdf

Pope, J., Berman, N., Tee, V., \& Williams, A. (2014). Improving young Australians' transition from school to work: Findings from the Worlds of Work (WOW) evaluation 2014. FYA. http://www.fya.org.au/wp-content/uploads/2015/08/FYA-2014-Evaluationreport-WOW.pdf

Rodriguez, J., Fox, H., \& McCambly, H. (2016). Work-based learning as a pathway to post-secondary and career success. Insights on Equity and Outcomes, 18, 1-7.

Savickas, M. L. (2011). New questions for vocational psychology: Premises, paradigms, and practices. Journal of Career Assessment, 19(3), 251-258.

Savickas, M. L. (2012). Life design: A paradigm for career intervention in the $21 \mathrm{st}$ century. Journal of Counseling \& Development, 90, 13-19.

Skorikov, V. B., \& Patton, W. (2007). Career development in childhood and adolescence. Sense Publishers.

Soresi, S., Nota, L., Ferrari, L., \& Ginevra, M. C. (2014). Parental influences on youth's career construction. In G. Arulmani, A. J. Bakshi, F. T. L. Leong, \& A. G. Watts (Eds.), Handbook of career development: International perspectives (pp. 149172). Springer.

Su, Y. (2014). Self-directed, genuine graduate attributes: The person-based approach. Higher Education Research \& Development, 33(6), 1208-1220.

Thomas, M., \& Gilfillan, G. (2019). Workforce participation measures: Budget review 2018-19 Index. Parliament of Australia. https://www.aph.gov.au/About_Parliament/ Parliamentary_Departments/Parliamentary_Library/pubs/rp/BudgetReview201819/ Workforce

Tomlinson, M. (2017). Forms of graduate capital and their relationship to graduate employability. Education + Training, 59(4), 338-352.

Torii, K. (2018). Connecting the worlds of learning and work: Prioritising schoolindustry partnerships in Australia's education system. Mitchell Institute. https://cica. org.au/wp-content/uploads/Connecting-the-Worlds-of-Learning-and-Work.pdf

Torii, K., \& O'Connell, M. (2017). Preparing young people for the future of work: Mitchell Institute report no. 01/2017. Mitchell Institute. http://www.mitchellinstitute. org.au/wp-content/uploads/2017/03/Preparing-young-people-for-the-future-of-work. pdf

Urbis. (2011). National career development strategy research project. Element 2: Synthesis report. DEEWR. https://docs.education.gov.au/documents/national-career-developmentstrategy-ncds-research-project-element-2-synthesis-report

Walsh, L. (2016). Educating generation next: Young people, teachers and schooling in transition. Palgrave MacMillan.

Watson, M., \& McMahon, M. (2017). Career exploration and development in childhood: Perspectives from theory, practice and research. Routledge.

Wyn, J., Cahill, H., Woodman, D., Cuervo, H., Chesters, J., Cook, J., \& Reade, J. (2017). Gen Y on Gen Y. Youth Research Centre, The University of Melbourne. 